\title{
Ability of students to recognise the relationship between using mobile apps for learning during fieldwork and the development of Graduate Attributes
}

\section{France, D. ${ }^{1}$, Powell, V. ${ }^{1}$, Mauchline, A.M. ${ }^{2}$, Welsh, K.E. ${ }^{1}$, Park, J.R. ${ }^{2}$, Whalley, W.B. ${ }^{3}$, Rewhorn, S. ${ }^{4}$}

${ }^{1}$ Department of Geography and Development Studies, University of Chester, Parkgate Road, Chester, CH1 4BJ, UK.

${ }^{2}$ School of Agriculture, Policy and Development, University of Reading, Whiteknights, P0 Box 237, Reading, RG6 6AR, UK.

${ }^{3}$ Department of Geography, University of Sheffield, Sheffield, S10 2TN, UK.

${ }^{4}$ University of Chester, Student Support and Guidance,, University of Chester, Parkgate Road, Chester, CH1 4BJ, UK.

Corresponding author: Derek France, d.france@chester.ac.uk-Tel: 01244-513-174

\begin{abstract}
The increasing importance of employability in Higher Education curricula and the prevalence of using mobile devices for field-based learning, prompted an investigation into student awareness of the relationship between the use of mobile apps for learning and the development of graduate attributes (and the link to employability). The results from post-fieldwork focus groups from four field courses indicated that students could make clear links between the use of a variety of mobile apps and graduate attribute development. The study suggests a number of mobile apps can align simultaneously with more than one graduate attribute. Furthermore, prior experience and the context of use can influence students' perceptions of an app and its link with different graduate attributes.
\end{abstract}

Keywords: graduate attribute, employability, fieldwork, iPad, m-learning

\section{Introduction}

The term 'graduate attribute' is relatively new to academia in the UK, but the theory behind it is integral to many student-development themes such as 'transferable skills', 'life skills', 'enterprise skills', 'life-long learning skills', 'employability skills' (Rust \& Froud, 2011) and 'wicked competences' (Knight \& Page, 2007). All of these terms focus on the drive to 
improve the employability of students, to present them as well-developed and highly desirable graduates, which universities are coming under increasing pressure to evidence (Bath et al., 2004). Barrie (2004) concisely described graduate attributes (GAs) as "the skills, knowledge and abilities of University graduates, beyond disciplinary content knowledge, which are applicable to a range of contexts".

The earliest use of the term 'graduate attributes' was in the early 1990s when the Higher Education Council in Australia defined them as "the skills, personal attributes and values, which should be acquired by all graduates regardless of their discipline or field of study. In other words, they should represent the central achievements of higher education as a process" (Higher Education Council Australia, 1992). Since then, studies in New Zealand have modelled a hierarchy of graduate development (Spronken-Smith et al., this volume), with multiple GAs forming a programme or institutional graduate profile (GP) and multiple GPs forming the overall institutional graduate outcomes (GOs) (Spronken-Smith et al., 2013). This hierarchy of graduate development is an essential step toward understanding how individual skills can be integrated to create academically successful students, who in turn become highly employable graduates.

Barrie (2004) suggested four over-arching features of GAs; (1) GAs should be achievable by all graduating students regardless of their discipline; (2) GAs relate to skills and knowledge sets achievable by graduates, not entry-level students; (3) GAs are more than just individual skills, but embrace a range of different skills sets illustrating a graduate's higher capabilities and knowledge; and (4) the development of GAs is the result of their progression through Higher Education. Many Higher Education Institutions (HEIs) have defined policies relating to GAs, for example University of Glasgow (Scotland), Oxford Brookes University (England), University of New South Wales (Australia), University of Otago (New Zealand) and University of Western Cape (South Africa), which all have well-defined GAs ranging from three to eighteen statements. Research undertaken by Rust \& Froud (2011) highlights that some universities were identified as making 'explicit lists' of GAs, and aligned them specifically with courses or modules. Rust \& Froud (2011), however, suggest that, with GAs restricted in this way, students can find it difficult to see the application of these transferrable skills to future employment possibilities. 
Graduate attributes can be developed during many academic and non-academic activities, but fieldwork can facilitate learning and skills development in a more general sense and provide opportunities to improve project management and self-management skills, the chance to stimulate independent thinking and reflection, develop team working and collaborative communication skills and more - all of which can contribute to enhancing employability. Fieldwork is an integral component of a wide range of Bioscience, Geography, Earth and Environmental Science undergraduate programmes. Student reflection and engagement during fieldwork can be promoted through the integration of technology into the learning activities (Fisher \& Baird, 2006; Jarvis \& Dickie, 2010; Mavroudi \& Jöns, 2011; France \& Wakefield, 2011; Kemp et al., 2012; Dando \& Chadwick, 2014 and Fuller \& France, this volume). The use of mobile technologies in the field is perceived to enhance fieldwork learning through improved speed, ease and immediacy of data collection, sharing, analysis and presentation (Welsh et al., 2013).

Tablet computers and smartphones are becoming increasingly more affordable and ubiquitous (Melhuish \& Fallon, 2010) and, due to their portability, they have the potential to be utilised extensively for learning support in the field (Welsh and France, 2012). Example activities include field mapping (Bunting and Fernley, 2011), recording and analysing field data in Pompeii (Ellis and Wallrodt, 2010), and recording geotagged data and the use of Twitter to encourage student engagement (France et al., 2013). The application of mobile devices to support student learning in a digitally enhanced world has not only the potential to develop digital literacy skills of the modern day Geography or Biology undergraduate, but also a number of wider graduate attributes leading to improved employability. Indeed, Arrowsmith et al. (2011) advocate the need for graduates with strong technological competencies and Whalley et al. (2011) suggest the $21^{\text {st }}$ century geographer will have to go beyond Geographical Information Systems (GIS) to encapsulate the breadth of digital communication, cartography and mobile learning.

It is critical that students can understand not only the knowledge content of their $\mathrm{HE}$ curriculum, but also what they have learnt and why. This deeper understanding builds 'knowing' students who can appreciate the skills and knowledge they have acquired during their studies and articulate their achievements when looking for employment (Knight \& Yorke, 
2003). As previously mentioned, fieldwork offers a unique learning environment that can support knowledge and skills acquisition and the use of mobile technologies can support this development further. Despite high student ownership of smartphones and tablet computers, a recent study suggested that many students are largely unaware of their potential to support learning (Woodcock et al., 2012). The aim of the research presented here was to expose students to learning activities in the field that were supported by the use of mobile technologies and to investigate whether the students understood, and could articulate, the graduate attributes (skills) they had developed.

\section{Methods}

Since 2012, the use of mobile devices with a range of learning-support apps have been incorporated into four residential field courses, which span different curriculum themes, levels, fieldwork locations and University settings (see Table 1). The two UK institutions participated in a nationally funded project to enhance fieldwork learning and hence the aims and evaluative techniques are standard across these geographically disparate locations. Even though the context and application of the mobile apps were discipline-dependant for each field course, a number of constants spanned each fieldwork activity. These included student briefing sessions with regards to using mobile devices in the field and guidance on how to effectively use a range of mobile apps to record data (quantitative or qualitative), map field locations, aid reflective learning, hone presentation skills and develop audio visual resources. It is accepted that apps can be used 'passively' in a transmission only manner: for example, in a social context in the form of unsolicited tweets or comments on a range of popular media topics. But the goal of incorporating the use of apps in these fieldwork contexts was to encourage a more 'active learning' approach. A complete list of the apps used within the four field courses and their teaching and learning utility, as expressed to the students at the start of the field course, are outlined in Table 2.

The research presented here was undertaken to determine whether students who use mobile devices and apps on fieldwork can relate these activities to specific graduate attributes. To enable this research, all students prior to fieldwork were advised on good practice in the use of mobile apps in relation to: qualitative and quantitative data collection, literature 
information gathering, data analysis and field presentations. The extent to which the use of mobile apps for fieldwork was perceived by students to contribute to their own graduate attribute development was assessed through post-fieldwork focus group discussions. All students on each field course were invited to volunteer to be part of the study, and the eventual numbers participating are shown in Table 1.

The focus group method was approved by the University of Chester Learning and Teaching Institute Research Ethics Committee and was designed to promote discussion in order to capture qualitative data. Each focus group lasted between 10 and 30 minutes. Focus group size varied from six to eleven students (see Table 1) and included both male and female participants with a mixture of ages (including mature students over 21). Each focus group was run by a member of staff who had attended the fieldtrip and had knowledge of the activities undertaken by the students; however they simply acted as a facilitator and did not influence the discussion. The first activity was to draw up a full list of the mobile apps that were used during teaching and learning activities on the field course and to encourage the students into a reflective mindset. The facilitator then explained the concept of graduate attributes based on the model of Barrie (2004) and described four relevant attributes as characterised by Oxford Brookes (2008). For the purposes of this research, the graduate attributes defined by Oxford Brookes University (2008) were selected as they are few in number and abide by the features suggested by Barrie (2004) and Bowden et al. (2000). All four of these attributes (set out below) can be developed via fieldwork activities.

- Academic literacy - demonstrable knowledge and skills related to disciplinary and professional specialties

- Research literacy - critically able to design and undertake small-scale research projects

- Critical self-awareness and personal literacy - understanding how to evaluate their own abilities, how to independently coordinate project activities and use interpersonal skills to relate to others

- Digital and information literacy - confident to adopt a range of technologies for personal, academic and professional use

Full descriptions of these graduate attributes are listed at Oxford Brookes University (2008). 
The students were asked to talk among themselves and to discuss whether their use of mobile apps on the field course had contributed to the development of any of the listed graduate attributes. They were then asked to work through the list of mobile apps (Table 2) one by one and specify which, if any, of the graduate attributes could be advanced through the use of each app in the field. When each student focus group reached consensus on the value of using a specific mobile app in the development of each GA the connection is shown as a tick " $(\checkmark)$ " “( $\checkmark \checkmark)$ ", “( $\checkmark \checkmark \checkmark)$ ”, or “( $\checkmark \checkmark \checkmark \checkmark)$ ". For example, Dropbox was seen to be valuable in developing 'Research Literacy' in three focus groups so " $(\checkmark \checkmark \checkmark)$ ” is shown for Dropbox on the grid.

The discussions were recorded using an audio recording device and specific, illustrative quotes were drawn from the recordings were manually coded on the emerging themes by one member of the research team.

\section{Results}

The data (Table 3) from the mapping exercise show all 27 mobile apps were associated with at least one graduate attribute; indeed, the results show $78 \%$ were aligned to two or more and a further $22 \%$ of apps (e.g. WWW, Prezi, Office, Mendeley, Keynote and GoodReader) to all four GAs. This suggests that the students consider these apps to be useful and multipurpose in developing a range of graduate skills, "I can just see how Office tools on the iPad can help with developing all thos skills [graduate attributes]" (FG-A) ${ }^{1}$.The table demonstrates that students understood that mobile app use could link to graduate attribute development and that often a mobile app can simultaneously align with more than one GA. However, Email, Evernote and Numbers app were recognised as the least affective to develop GAs.

Overall, the students in the focus groups were able to quickly reach a consensus on the pedagogic and developmental value of each app, which related strongly to their group experience of using it for learning activities on their field course. The fact that they were presented with a framework did not influence the fact that this understanding was gained from their personal experience and demonstrates that they implicitly understood the link with GA development. 
The quantitative data presented from Table 3 indicates the most frequently recognised GA to be developed through mobile apps was research literacy, with the least as academic literacy. This might reflect the nature of the fieldwork activities and hence the types of apps used.

Comments made by the students in the focus groups referred to how the mobile apps and tablet devices made them feel more professional whilst undertaking public surveys, as well as improving their presentation skills. This suggests that personal identity and professional values are an important part of GAs (as highlighted by Hill \& Walkington in this volume). Students recognised that the skills they learnt in the field through using mobile apps could be transferred to future assessments and future employment situations; "it just helps you be more accurate, and when you write your dissertation up that's what you want" (FG-A); "using apps in the field on the iPad must be good for getting a job" (FG-Na) and "I think using technology in general makes you more employable...mobile devices and apps are a bonus" (FGS). This connection between fieldwork exercises, future assessment and employment suggests development of graduate skills awareness in the students and an ability to make connections between GAs and mobile apps.

Students frequently referred to using the mobile apps to geo-reference their field data and to develop field maps. They also noted that accessing mobile apps helped them to be more effective researchers, readily using pre-loaded Dropbox resources (such as publications, data and maps) and the Internet "having access to the papers, photographs and the web on the iPad made us more efficient researchers" (FG-S). For example, in Naples the students needed to conduct field questionnaires amongst the Italian-speaking local populous. To facilitate this, pre-fieldwork students adapted a pre-existing questionnaire that was then translated into Italian and transposed into the Polldaddy survey app. Students could then take iPads into the field and conduct the surveys in a professional manner. With the access to Polldaddy and a range of other mobile apps on an iPad, students considered the iPad was an "essential tool for research" (FG-Na).

Students found that Skitch was a useful app for reflection, as it allows the annotation of a photograph with words or sketches. Fotobabble works in a similar fashion, allowing students to add an audio reflection to an image. In Naples students visiting a volcanic field around Vesuvius successfully used the Skitch app to annotate both field photography and field maps 
of the area with their field comments and interpretations. The students commented in the focus group that, "these apps [Skitch and Fotobabble] allow us to refer back to our [annotated] images later to support our research" (FG-Na).

The main finding from this research is that the students were able to consider discursively their use of mobile apps during field learning activities and reflect on the skills and GAs they developed as a consequence of using these learning support tools. Had the students been unable to make this connection, the result from the focus groups would have been a simple discussion around the utility provided by the apps, not the deeper understanding of the academic and wider value of the use of these software tools that was evident from their discussions. This can be exemplified from the focus group comments below, highlighting more broadly the linkages to developing all four GAs:

"I think the one massive thing that is amazing from using iPads in Iceland is that I have become more organised with my field data and research papers [Personal literacy GA]" (FG-A).

"Tweets we sent during the [fieldwork] day fuelled our discussions in the evening, which in turn contributed to our reflective reports [Research literacy GA]" (FG-NY).

"When I give a presentation in the field using an iPad a feel more confident with the apps [Digital literacy]" (FG-S).

"Using Google Earth on my mobile helped me see and understand the landscape around Vesuvius" [Academic literacy]" (FG-Na).

\section{Discussion}

The data reveal that the students' understanding of the value of mobile app use in the development of GAs differed depending on how each mobile app was utilised during their field course and the students' prior knowledge. One student identified that they "definitely benefitted from using the iPads last year in Slapton $\left[1^{\text {st }}\right.$ year field course], I knew which [mobile] app to use and how it could help with my data collection" FG-NY). It is evident that one app could be used in two separate contexts and produce different student perceptions of how they could be applied to GAs. For example, the geo-referencing app GeoSpike could be 
used as a navigation tool, a plotting tool or as a search tool for previous information about a field site and contributed to Academic Literacy, Research Literacy or Digital Information Literacy.

It was interesting to note that the digital and information literacy category appears to have been overlooked by many students in a number of focus groups, with most apps not being identified as applicable for improving their digital literacy. This could be that many focus groups did not recognise their importance for developing digital literacy. However, it has to be recognised that the definition of the GA may have resulted in confusion within the focus group.

However, using apps to enhance or support learning, regardless of the device owned, has to be driven by the pedagogical need rather than the availability of the technology (Welsh et al., 2013). Social media, for example, can be a useful tool for cross-team communication, to develop insightful personal reflection and as a place to show student videos. It is known that in 2013 over 1.19 billion people were signed up to Facebook, 883 million to Twitter and YouTube had 3.5 billion views per day - more than 1 billion views per day through mobile devices (Econsultancy.com, 2013). These social media sites can be used to improve a student's digital literacy as well as their critical self-awareness, but if students are unguided these sites can provide a distraction to effective learning rather than an aid to it.

In this research, students were critical about their use of technologies and gave some examples where they believe the pedagogy was not the focus. "Some people might use the maps just to go around, some people might use them for academic work to locate the site. It depends how you choose to use them ... in a context" (FG-NY). The students were not necessarily adopting the devices for personal use, but the mobile apps chosen for use could have been utilised more effectively by an insightful student. By contrast, students sometimes discovered new ways to use a device, beyond the scope that the tutor had originally intended. Students also suggested new apps for use, or utilised pre-installed apps for a new purpose. "Often [the iPad] is given to us to use in certain way, but we want to use them differently" (FGNY). Allowing students to go beyond the rulebook and experiment with these mobile apps can promote spontaneous development of their digital literacy skills, in a productive learning environment. 
Students perceived that apps such as Mendeley, Keynote, Prezi, Office, GoodReader and the WWW could be linked to all four of the GAs that are the focus of this paper (see Table 2 for app information). These apps can be regarded as non-discipline-specific whilst still promoting a range of academic practices. Students considered that other apps, such as Email, Evernote and Numbers app to be limited in advancing GA development. However, the student perception of mobile app alignment with graduate attributes may change with student experience and the fieldwork context.

\section{Conclusions}

During post-fieldwork focus groups with students, key perceptions were accessed in relation to how these students connected mobile app use in a pedagogic setting with graduate attributes. The students completed an exercise where, as a group, they mapped mobile apps to a set of pre-selected GAs. Students were able to map GAs using the grid and to be reflective regarding their own use of the mobile apps in the fieldwork environment, which led to the identification of two overarching outcomes from this research:

- Using a mobile app can provide linkages to more than one GA, having a multi-beneficial nature that can promote several skills simultaneously.

- The methods through which students use mobile apps can influence how they perceive linkages between mobile apps and GAs - encouraging simple links through lowintensity use or complex links through critical investigative use of the apps.

Students were clear and confident about linking these mobile apps to GAs (Table 3) and were usually able to differentiate between the four GAs. Student focus groups identified key nondisciplinary apps that they considered were linked to all GAs, including Keynote, Prezi, Office, GoodReader and WWW. Several discipline-specific apps were identified, such as GeoSpike, GPS Log and Google Earth which could strengthen GA development. One GA was overlooked by many of the student focus groups, with many apps not being perceived as linking to digital literacies (as this may have been implicit in their thinking during the exercise). Furthermore, research literacy appears to be strengthened by the use of mobile apps and and academic literacy the least. 
Further research is required to investigate which mobile learning activities are most effective for developing GAs over the course of an undergraduate module or programme. In the interim, the results from this research offer an encouraging insight into the transferability of mobile app use for developing skill-sets that students can take beyond their university programme into a range of previously inaccessible locations.

\section{Acknowledgements}

This work was funded by a research grant from the Higher Education Academy and continuation funds from the British Ecological Society. The authors would like to thank the anonymous reviewers for their constructive comments that helped us to substantially rewrite and improve this article.

\section{Notes}

${ }^{1}$ These annotations refer to quote given by specific fieldwork focus groups (FG) locations from Akureyri, Iceland (FG-A), New York, USA (FG-NY), Sorbas, Spain (FG-S) or Naples, Italy (FG-Na)

\section{References}

Arrowsmith, C., Bagoly-Simo', P., Finchum, A., Oda, K. \& Pawson, E. (2011) Student employability and its implications for geography curricula and learning practices, Journal of Geography in Higher Education, 35, 365-377.

Barrie, S. C. (2004). A research-based approach to generic graduate attributes policy. Higher Education Research \& Development, 23(3), 261-275.

Bath, D., Smith, C., Stein, S., \& Swann, R. (2004). Beyond mapping and embedding graduate attributes: bringing together quality assurance and action learning to create a validated and living curriculum. Higher Education Research \& Development, 23(3), 313-328.

Bowden, J., Hart, G., King, B., Trigwell, K. \& Watts, O. (2000). Generic capabilities of ATN university graduates. Access from the National Library of Australia and Partners on 22 August 2014: http://pandora.nla.gov.au/pan/34352/200305130000/www.clt.uts.edu.au/ATN.grad.cap.project.index.html

Bunting, P. \& Fearnley, C. (2011) Using iPads and applications for geography fieldwork. Retrieved from: cingFieldworkLearningShowcaseEvent.pdf Retrieved 09.03.14 
Dando, C. E. \& Chadwick, J. J. (2014) Enhancing Geographic Learning and Literacy Through Filmmaking. Journal of Geography, 113, 78 -84.

Econsultancy.com. (2013). 20 mind blowing social media statistics three years later. Retrieved on 20 August 2014: https://econsultancy.com/blog/63918-20-mind-blowingsocial-media-statistics-three-years-later\#i.1n2lt2kizpezwv.

Ellis, S. \& Wallrodt, J. (2010) Using tablet PCs to support field documentation. Retrieved from: https://www.ocs.soton.ac.uk/index.php/CAA/2012/paper/view/680

Fisher, M. \& Baird, D. E. (2006). Making mLearning work: Gen Y, learning and mobile technologies, Journal of Educational Technology Systems, 35, 3-30.

France, D. \& Wakefield, K. (2011). How to produce a digital story, Journal of Geography in Higher Education, 35, 617-623.

France, D., Whalley, W. B. \& Mauchline, A. L. (2013) Using mobile devices to enhance undergraduate field research. CUR Quarterly, 34, 38-42.

Fuller, I. C., \& France, D. (in this volume) Does digital video enhance student learning in fieldbased experiments and develop graduate attributes beyond the classroom? Journal of Geography in Higher Education,

European Higher Education Area (EHEA). (12/3/10). Budapest-Vienna Declaration on the European Higher Education Area. Retrieved on 20 August 2014 from: http://www.ehea.info/news-details.aspx?Articleld=59

Higher Education Council (HEC) Australia. (1992). Achieving quality. Canberra: Australian Government Publishing Service. In: Barrie (2004) A research-based approach to generic graduate attributes policy. Higher Education Research \& Development, 23(3), 261-275.

Hill \& Walkington in this volume

Jarvis, C. \& Dickie, J. (2010) Podcasts in support of experiential field learning. Journal of Geography in Higher Education, 34, 173-186.

JISC (2013) Developing digital literacies. Retrieved on 2 October, 2014, from http://www.jisc.ac.uk/developingdigitalliteracies

Kemp, J., Mellor, A., Kotter, R. \& Oosthoek, J. (2012) Student-produced podcasts as an assessment tool: an example from geomorphology, Journal of Geography in Higher Education, 36, 117-130.

Knight, P. \& Page, A. (2007) The assessment of 'wicked' competences: Report to the Practicebased Professional Learning Centre. Retrieved from the Open University site on 20 Aug 2014: http://www.open.ac.uk/cetlworkspace/cetlcontent/documents/460d21bd645f8.pdf

Knight, P.T. \& Yorke, M. (2003) Employability and Good Learning in Higher Education. Teaching in Higher Education, 8(1), 3-16.

Mavroudi, E. \& Jöns, H. (2011) Video Documentaries in the Assessment of Human Geography Field Courses. Journal of Geography in Higher Education, 35, 579-598.

Melhuish, K. \& Fallon, G. (2010) "Looking to the Future: M-learning with the iPad." Computers in New Zealand Schools. Learning, Leading, Technology.22 (3) 1-16. 
Oxford Brookes University (2008). A Mapping of Graduate Attributes v 2. Retrieved on 22 August 2014 from:

http://www.brookes.ac.uk/services/ocsld/sese/graduate_attributes.pdf

Rust, C. \& Froud, L. (2011) 'Personal literacy': the vital, yet often overlooked, graduate attribute. Journal of Teaching and Learning for Graduate Employability, 2(1), 28-40

Spronken-Smith, R., Bond, C., McLean, A., Frielick, S., Smith, N., Jenkins, M., \& Marshall, S. (2013). How to engage with a graduate outcomes agenda: A guide for tertiary education institutions. Wellington: Ako Aotearoa. Retrieved on 22 September 2014 from https://akoaotearoa.ac.nz/download/ng/file/group-5324/how-to-engage-with-agraduate-outcomes-agenda-a-guide-for-tertiary-education-institutions.pdf

Spronken-Smith, R., McLean, A., Smith, N., Bond, C., Jenkins, M., Marshall, S., \& Frielick, S., (this volume). A toolkit to implement graduate attributes in geography curricula. Journal of Geography in Higher Education

Welsh K. \& France, D. (2012) Smartphone and fieldwork. Geography, 97, 47-51.

Welsh, K. E., Mauchline, A. L., Park, J. R., Whalley, W. B., \& France, D. (2013). Enhancing fieldwork learning with technology: practitioner's perspectives. Journal of Geography in Higher Education, 37, 399-415.

W. Brian Whalley, Saunders, A., Lewis, R. A., Buenemann, M. \& Sutton, P. C. (2011) Curriculum Development: Producing Geographers for the 21st Century, Journal of Geography in Higher Education, 35,(3) 379-393

Woodcock, B., Middleton, A. \& Nortcliffe, A. (2012) Considering the Smartphone Learner: an investigation into student interest in the use of personal technology to enhance their learning. Student Engagement and Experience Journal, 1, 1-15. 
Table 1. Meta data for four undergraduate field courses examined in this paper

\begin{tabular}{|c|c|c|c|c|}
\hline $\begin{array}{l}\text { Level \& } \\
\text { fieldwork } \\
\text { location }\end{array}$ & $\begin{array}{l}\text { Focus of } \\
\text { fieldwork }\end{array}$ & $\begin{array}{l}\text { Recommended mobile } \\
\text { app use }\end{array}$ & $\begin{array}{l}\text { No. of } \\
\text { students on } \\
\text { the field } \\
\text { course }\end{array}$ & $\begin{array}{l}\text { No. of } \\
\text { students in } \\
\text { the focus } \\
\text { group }\end{array}$ \\
\hline $\begin{array}{l}\text { Year 2, USA, } \\
\text { New York, (2013), } \\
\text { University of } \\
\text { Chester }\end{array}$ & $\begin{array}{l}\text { Regeneration and } \\
\text { Immigration }\end{array}$ & $\begin{array}{l}\text { Twitter, Dropbox WWW, } \\
\text { Camera }\end{array}$ & 10 & 6 \\
\hline $\begin{array}{l}\text { Year 2, Spain } \\
\text { Sorbas, (2012), } \\
\text { University of } \\
\text { Chester }\end{array}$ & $\begin{array}{l}\text { Sustainable } \\
\text { Communities }\end{array}$ & $\begin{array}{l}\text { Twitter, } \\
\text { Splice, Dropbox, } \\
\text { GoodReader, WWW, } \\
\text { Skitch Office, Camera }\end{array}$ & 10 & 8 \\
\hline $\begin{array}{l}\text { Year 3, Iceland, } \\
\text { Akureyri (2013), } \\
\text { University of } \\
\text { Reading }\end{array}$ & $\begin{array}{l}\text { Microbes in } \\
\text { Extreme } \\
\text { Environments }\end{array}$ & $\begin{array}{l}\text { GPS Log, Dropbox, } \\
\text { GoogleDrive, Geospike, } \\
\text { Splice, iMovie, Yammer, } \\
\text { Camera, Twitter }\end{array}$ & 22 & 9 \\
\hline $\begin{array}{l}\text { Year 3, Italy } \\
\text { Naples, (2012), } \\
\text { University of } \\
\text { Chester }\end{array}$ & $\begin{array}{l}\text { Volcanic Hazards } \\
\text { and Risk }\end{array}$ & $\begin{array}{l}\text { Polldaddy, PDF Reader, } \\
\text { Dropbox, WWW, } \\
\text { Keynote, Camera, Skitch }\end{array}$ & 23 & 11 \\
\hline
\end{tabular}


Table 2: Mobile apps available for the four field courses with brief description and teaching and learning utility

\begin{tabular}{|c|c|c|}
\hline Mobile App & Description & Teaching and Learning Utility \\
\hline Camera & Record digital imagery or video & $\begin{array}{l}\text { Develop visual resources for self and } \\
\text { group reflection and geo-referenced } \\
\text { photographs }\end{array}$ \\
\hline Decibel 10th & $\begin{array}{l}\text { Basic sound monitor, peaking at } 110 \text { decibels } \\
\text { (depending on the device microphone } \\
\text { capacity) }\end{array}$ & $\begin{array}{l}\text { Record ambient noise, providing a } \\
\text { measure of tranquillity }\end{array}$ \\
\hline $\begin{array}{l}\text { Dropbox / Google } \\
\text { Drive / Evernote }\end{array}$ & $\begin{array}{l}\text { Cloud-based data storage and file } \\
\text { synchronization between devices }\end{array}$ & $\begin{array}{l}\text { Group based repository for data and } \\
\text { photographs. Evernote can be used as } \\
\text { a digital field note book }\end{array}$ \\
\hline Dragon Dictation & $\begin{array}{l}\text { Audio-dictation application that can convert } \\
\text { spoken word into text }\end{array}$ & Transcribe audio interviews to text \\
\hline Flipboard & $\begin{array}{l}\text { Collates newsfeeds from a range of social } \\
\text { media feeds and websites }\end{array}$ & $\begin{array}{l}\text { Secondary data collection through a } \\
\text { mash up of social media feeds }\end{array}$ \\
\hline Fotobabble & $\begin{array}{l}\text { Allows users to record and embed an audio } \\
\text { file with a photograph }\end{array}$ & $\begin{array}{l}\text { Personal or group reflections of } \\
\text { photos/imagery of fieldwork }\end{array}$ \\
\hline $\begin{array}{l}\text { Geospike / } \\
\text { GPS Log }\end{array}$ & $\begin{array}{l}\text { Geographical information system that allows } \\
\text { the user to record and plot geo-referenced } \\
\text { information, e.g. photographs on a map }\end{array}$ & $\begin{array}{l}\text { Provide geo-referenced photographs } \\
\text { and associated field site descriptions }\end{array}$ \\
\hline Google Earth & $\begin{array}{l}\text { Map-viewing application, used for site } \\
\text { reference, directions and Streetview }\end{array}$ & $\begin{array}{l}\text { Aerial photography and maps of field } \\
\text { sites pre/peri and post-fieldwork }\end{array}$ \\
\hline $\begin{array}{l}\text { Goodreader / } \\
\text { PDF reader }\end{array}$ & $\begin{array}{l}\text { Enabling PDF/word documents to be read on } \\
\text { mobile devices and retrieved from cloud- } \\
\text { based data storage }\end{array}$ & $\begin{array}{l}\text { Reference resource for web articles } \\
\text { and web-based journal articles }\end{array}$ \\
\hline iMovie / Splice & $\begin{array}{l}\text { Allows users to capture, edit and share video } \\
\text { over the web }\end{array}$ & $\begin{array}{l}\text { Develop self-reflection through the } \\
\text { creation of short reflective videos }\end{array}$ \\
\hline Keynote/Prezi & $\begin{array}{l}\text { Alternative presentation software to } \\
\text { PowerPoint }\end{array}$ & $\begin{array}{l}\text { To support and enable student } \\
\text { presentations }\end{array}$ \\
\hline Mendeley & $\begin{array}{l}\text { Academic software that indexes and } \\
\text { organizes PDF documents and allows them to } \\
\text { be shared for bibliographic purposes }\end{array}$ & $\begin{array}{l}\text { To develop bibliographic referencing } \\
\text { skills }\end{array}$ \\
\hline Polldaddy & $\begin{array}{l}\text { Remote survey tool, allowing users to gather } \\
\text { surveys on their mobile devices }\end{array}$ & $\begin{array}{l}\text { To enable students to collect } \\
\text { perception survey data on fieldwork } \\
\text { on their mobile devices }\end{array}$ \\
\hline $\begin{array}{l}\text { Office / Numbers/ } \\
\text { Pages }\end{array}$ & $\begin{array}{l}\text { Includes word processing, spreadsheet and } \\
\text { presentation office tools }\end{array}$ & $\begin{array}{l}\text { In-the-field data collection and } \\
\text { analysis, presentation skills, note } \\
\text { taking, reflective report writing }\end{array}$ \\
\hline $\begin{array}{l}\text { Twitter / Facebook } \\
\text { / Yammer }\end{array}$ & $\begin{array}{l}\text { Social networking apps that offer different } \\
\text { levels of privacy options and newsfeed access }\end{array}$ & $\begin{array}{l}\text { Maintain group understanding across } \\
\text { a large geographical area and to } \\
\text { develop self-reflection }\end{array}$ \\
\hline WWW & Access to web based resources and services & $\begin{array}{l}\text { Web based resources to support } \\
\text { learning, access secondary data and } \\
\text { research information }\end{array}$ \\
\hline
\end{tabular}


Table 3. Strength of student recognition that individual mobile apps can contribute to development of a range Graduate Attributes.

\begin{tabular}{|c|c|c|c|c|}
\hline App & $\begin{array}{l}\text { Academic } \\
\text { literacy }\end{array}$ & $\begin{array}{l}\text { Research } \\
\text { literacy }\end{array}$ & $\begin{array}{l}\text { Critical self- } \\
\text { awareness }\end{array}$ & $\begin{array}{c}\text { Digital and } \\
\text { information literacy }\end{array}$ \\
\hline Camera & $\checkmark$ & & $\checkmark$ & $\checkmark \checkmark$ \\
\hline Decibel $10^{\text {th }}$ & $\checkmark$ & $\checkmark$ & & \\
\hline DragonDictation & $\checkmark$ & & $\checkmark$ & \\
\hline Dropbox & & $\checkmark \checkmark \checkmark$ & $\checkmark \checkmark$ & $\checkmark \checkmark$ \\
\hline Email & & & & $\checkmark$ \\
\hline Evernote & $\checkmark$ & & & \\
\hline Facebook & & & $\checkmark$ & $\checkmark$ \\
\hline Flipboard & & $\checkmark$ & & $\checkmark$ \\
\hline Fotobabble & & & $\checkmark$ & $\checkmark$ \\
\hline GeoSpike & $\checkmark$ & $\checkmark$ & & $\checkmark$ \\
\hline GoodReader & $\checkmark$ & $\checkmark$ & $\checkmark$ & $\checkmark$ \\
\hline Google Earth & $\checkmark$ & & & $\checkmark$ \\
\hline GPS Log & $\checkmark$ & $\checkmark$ & & $\checkmark$ \\
\hline iMovie & & & & $\checkmark$ \\
\hline Keynote & $\checkmark \checkmark$ & $\checkmark \checkmark$ & $\checkmark$ & $\checkmark$ \\
\hline Mendeley & $\checkmark$ & $\checkmark$ & $\checkmark$ & $\checkmark$ \\
\hline Numbers & & $\checkmark$ & & \\
\hline Pages & & $\checkmark$ & $\checkmark$ & \\
\hline PDF Reader & $\checkmark$ & $\checkmark$ & & \\
\hline Office & $\checkmark \checkmark$ & $\checkmark \checkmark \checkmark$ & $\checkmark$ & $\checkmark$ \\
\hline Polldaddy & & $\checkmark \checkmark \checkmark$ & & \\
\hline Prezi & $\checkmark \checkmark$ & $\checkmark \checkmark$ & $\checkmark$ & $\checkmark$ \\
\hline Skitch & $\checkmark$ & & $\checkmark \checkmark$ & $\checkmark$ \\
\hline Splice & & $\checkmark$ & $\checkmark$ & $\checkmark$ \\
\hline Twitter & & $\checkmark$ & $\checkmark \checkmark \checkmark$ & $\checkmark$ \\
\hline WWW & $\checkmark \checkmark$ & $\checkmark \checkmark \checkmark$ & $\checkmark$ & $\checkmark \checkmark$ \\
\hline Yammer & $\checkmark$ & & $\checkmark \checkmark$ & \\
\hline Total & 20 & 27 & 21 & 22 \\
\hline
\end{tabular}

